\title{
"Debating as a classroom tool for adapting learning outcomes to the European higher education area"
}

\author{
Juan Luis Jiménez, Jordi Perdiguero and Ancor Suárez
}




\section{$\bigoplus_{\circledast}|\mathrm{R}| \mathrm{E}|\mathrm{A}|$}

Institut de Recerca en Economia Aplicada Regional i Pública Research Institute of Applied Economics

\section{Universitat de Barcelona}

Av. Diagonal, $690 \bullet 08034$ Barcelona

WEBSITE: www.ub.edu/irea/•CONTACT: irea@ub.edu

The Research Institute of Applied Economics (IREA) in Barcelona was founded in 2005, as a research institute in applied economics. Three consolidated research groups make up the institute: AQR, RISK and GiM, and a large number of members are involved in the Institute. IREA focuses on four priority lines of investigation: (i) the quantitative study of regional and urban economic activity and analysis of regional and local economic policies, (ii) study of public economic activity in markets, particularly in the fields of empirical evaluation of privatization, the regulation and competition in the markets of public services using state of industrial economy, (iii) risk analysis in finance and insurance, and (iv) the development of micro and macro econometrics applied for the analysis of economic activity, particularly for quantitative evaluation of public policies.

IREA Working Papers often represent preliminary work and are circulated to encourage discussion. Citation of such a paper should account for its provisional character. For that reason, IREA Working Papers may not be reproduced or distributed without the written consent of the author. A revised version may be available directly from the author.

Any opinions expressed here are those of the author(s) and not those of IREA. Research published in this series may include views on policy, but the institute itself takes no institutional policy positions. 
The creation of the European Higher Education Area has meant a number of significant changes to the educational structures of the university community. In particular, the new system of European credits has generated the need for innovation in the design of curricula and teaching methods. In this paper, we propose debating as a classroom tool that can help fulfill these objectives by promoting an active student role in learning. To demonstrate the potential of this tool, a classroom experiment was conducted in a bachelor's degree course in Industrial Economics (Regulation and Competition), involving a case study in competition policy and incorporating the techniques of a conventional debate (presentation of standpoints, turns, right to reply and summing up). The experiment yielded gains in student attainment and positive assessments of the subject. In conclusion, the incorporation of debating activities helps students to acquire the skills, be they general or specific, required to graduate successfully in Economics.

JEL classification:. A23, B4, I2.

Keywords: European Higher Education Area; Debating; Industrial Organization; Academic Success; European Credit Transfer System.

Juan Luis Jiménez, Grupo de Innovación Educativa en Economía e Historia (GIZEH). Facultad de Economía, Empresa y Turismo. Universidad de Las Palmas de Gran Canaria. Despacho D. 2-12. Campus de Tafira. 35017. Las Palmas. E-mail: jlijmenez@daea.ulpgc.es, Ph: +34 928458191.

Jordi Perdiguero is Associate Professor at University of Barcelona, Departament de Política Econòmica i Estructura Econòmica Mundial. E-mail: jordi.perdiguero@ub.edu, Ph: +34 934020813.

Ancor Suárez, Grupo de Investigación en Economía de las Infraestructuras y el Transporte. Departamento de Análisis Económico Aplicado; Facultad de Economía, Empresa y Turismo. Universidad de Las Palmas de Gran Canaria.. E-mail: asuarez@acciones.ulpgc.es; Ph: + 34928458 208.

\section{Acknowledgements:}

Thanks are due to Javier Campos and members of the "Grupo de Innovación Educativa en Economía e Historia (GIZEH)" of Universidad de Las Palmas de Gran Canaria. The usual disclaimer applies. 
Tell me and I forget. Teach me and I remember. Involve me and I learn.

(B. Franklin)

\section{Introduction}

In Bologna in 1999 a declaration was made promoting the harmonization of the education systems of the European Union's member states. The main objectives of the Bologna Declaration, today ratified by 46 countries, included the creation of a common higher education area with the revision of degree structures, credit systems, exchange programs, quality assurance and lifelong learning. Among the measures introduced to achieve these goals was the European Credit Transfer and Accumulation System (ECTS) ${ }^{1}$, the benchmark for comparing student attainment. This credit system seeks to assess all aspects, as well as theoretical and practical experiences, that contribute to the student's learning process and learning outcomes. In response, there is a growing need for universities to engage in more innovative and creative curricula design, emphasizing the introduction of new methods and teaching activities, which extend beyond the simple setting of a final exam.

Higher education institutions throughout Europe have come to stress the importance of their teaching mission and the need for ongoing curricular reform geared toward the development of learning outcomes. This requires empowering individual learners, developing new approaches to teaching and learning, introducing effective support and guidance structures and designing curricula focused more clearly on the learner. The approach promoted by the European Higher Education Area (EHEA) is one in which academics, in close cooperation with student and employer representatives, can continue to develop learning outcomes for a growing number of subject areas. Ultimately, the Bologna reform promotes a learner-centered system and a more active role for the student that combines attendance at lectures with other learning methods, such as the one proposed here, debating.

\footnotetext{
${ }^{1}$ The ECTS was introduced in 2010. Sixty ECTS credits are attached to the workload of an academic year, with one credit corresponding to 25-30 hours of work, including lectures, self-study, internships, seminars and other educational activities.
} 
Changes in educational models require innovative teaching techniques and learning methods that facilitate understanding while providing the practical focus intended by the EHEA. In the specific case of the teaching of economics, Colander (2005) claims that there is often a gap between what economists do and what they teach. There is a need, therefore, to alternate the traditional teaching methods used in theoretical and applied economics with participatory techniques that enable students to internalize knowledge further and, thus, to bridge the aforementioned gap as they seek to confront current social realities.

This paper has three main objectives: first, to describe a tool, specifically designed for a bachelor's degree course in Industrial Economics but applicable in other subjects, to promote the implementation of the EHEA; second, to analyze whether the tool is perceived as positive by the students through the conducting of a survey; and, third, to show how the introduction of educational tools, such as debating, can help students acquire the skills targeted in a bachelor's degree in Economics.

Following on from this introduction, and after conducting a review of the relevant literature (section 2 ), section 3 describes the debating tool, its objectives, the scope of the study and the standards adhered to. In section 4 we analyze the results of the survey conducted among the students, and report the main findings of the study, which are largely positive both from the perspective of the teachers and students. 


\section{LITERATURE REVIEW}

The literature on education in economics has until recently reported mixed findings on the benefits of the use of experimental approaches in the teaching of economics. Cardell et al (1996), for example, showed that the application of these practices in introductory courses to micro- and macroeconomics did not lead to a statistically significant improvement in student learning. However, most papers do obtain positive outcomes. Emerson and Taylor (2004), for example, taught one group of students using classroom experiments and another using conventional teaching techniques, and found that the former obtained better results.

Dickie (2006), in testing the hypotheses that classroom experiments and the use of grade incentives rewarding participation positively affect learning, conducted a number of experiments (contrasted with conventional lectures in economics) during a 15-week semester in Mississippi, temporarily introducing or withdrawing the existence of incentives for student participation, and controlling for student aptitude and other characteristics in a multiple-regression framework. His results are in line with those reported by Emerson and Taylor (2006), highlighting the gains in student learning attributable to experiments in certain subjects (in this case, an introductory course to microeconomics). However, Dickie (2006) found that grade incentives had an adverse effect on learning and that they may even partly offset the beneficial impact of classroom experiments. This latter finding is supported by Holt's (1999) contention that the use of grade incentives conflicts with teaching objectives. For this reason, in our experiment, no incentive is offered to students that might result in their being deviated from their basic learning purpose.

In any event, Dickie (2006) noted that half the students reported that experiments helped them learn better than just by attending lectures, compared with $12.5 \%$ who found lectures more helpful. McGoldrick (2008) described a course, involving a project of the student's choosing, designed to promote student interest in economics and to increase their academic gains. She reports positive results for a technique aimed at modeling what it means to "act like an economist" and at reinforcing students' research skills.

A further paper that examines the usefulness of classroom experiments in the teaching of economics is Meister and Anderson (2007). The authors describe how the conducting of an experiment can encourage students to apply economic theory and thereby enhance their understanding of that theory in relation to real-world business cases. In this particular instance, the authors simulated an auction to buy US Airways with students representing two potential 
bidders, United Airlines and American Airlines (as had indeed occurred in 1995). The students learn that the equilibrium of the sequential game is that neither firm eventually makes a bid.

The present study could be incorporated within the literature on collaborative learning, one of the most fully developed areas of research in educational literature. Slavin (1989, 1992, 1995) identified a number of different perspectives on collaborative learning, namely, motivational, cognitive and social cohesion. Johnson and Johnson (1992) focused on the motivational perspective (of particular interest to our study) by creating scenarios in which students are given incentives to achieve their individual goals and to help and encourage their peers to achieve group objectives. Other studies have sought to identify optimal conditions for teaching. Arias and Walker (2004) examined the relationship between class size and student performance, concluding that small class size has a positive impact on student performance. This points to the benefits of conducting classroom experiments with a small number of participants.

The classroom tool proposed in this paper, debating, is widely recognized as an effective method for promoting student learning. Lund et al. (2007), for example, show that debating can enhance the depth of knowledge acquired by students and is positive for the learning and assimilation of concepts and even the elaboration of new knowledge (see, Baker, 1999). Discussions of the use of debating in economic education are few and far between, but Ruiz (2008) and Carrasco et al (2006) both focus on its application as a teaching and evaluating tool in the framework of the European Higher Education Area. They report that debating can be extremely helpful in encouraging independent learning.

Unlike previous studies, this paper brings together an empirical analysis as applied to a debating activity, a real-world case from competition policy, and the techniques of conventional debating (presentation of standpoints, turns, right to reply and summing up). Similarly, we present a descriptive analysis of the results of this experiment conducted at the University of Las Palmas de Gran Canaria (Spain), in the subject of Industrial Economics /I (taught in the fourth and final year of the bachelor's degree in Economics). 


\section{DEBATING AND LEARNING}

Industrial Economics II is an optional course taught to fourth year students enrolled in the bachelor's degree in Economics at the University of Las Palmas de Gran Canaria. The course is taught in two distinct but related parts - Part I: the analysis of government regulation of business, and Part II: competition policy. Part I represents between 40 and $50 \%$ of the final grade, depending on the specific syllabus. Part II is evaluated (50\%) by class work (including, presentations, exercises and tests, etc.) and by participating in a debating session $(50 \%)$. This means that $25 \%$ of the final grade awarded on the course depends on the student's performance in a debate.

The debate involves two teams of students (two to three team members each) defending opposite positions in a real-world case involving competition policy. Cases are assigned at random to the groups at least one month before the debate is scheduled to be held. They are informed of the rules of the debate in advance and are warned to adhere to them strictly in preparing their cases. All members of the group must participate individually in the oral presentation of their case, but it is up to the team to program these interventions. However, individual interventions should be largely similar in terms of time, difficulty of exposition, replies, etc. The teacher acts as the judge, sometimes with the assistance of a professional guest from the field of competition policy ${ }^{2}$.

The aim of the debate is that participants draw on the theoretical and empirical concepts, taught in the conventional classes dedicated to competition policy, and apply them to a real-world case (one that has already been decided by national competition authorities). Cases include restrictive competition practices (price fixing, non-compete clauses, abuse of dominant position, etc.) and market concentration processes.

The debate itself is organized as follows (note, times are maximums and should not be exceeded):

i) Each team has twenty minutes to present the main concepts in defense of their position.

ii) There is a break of eight minutes to allow the teams to reflect.

iii) Each team has seven minutes to rebut the arguments presented by the other party, or to reaffirm their own arguments. However, they are not permitted to introduce any new arguments.

\footnotetext{
2 Note, to avoid any potential classroom conflict, no definitive decision is given.
} 
iv) Teams have five minutes to sum up. Again, teams may not introduce any new arguments, but must limit themselves to reaffirming their earlier positions or any new positions they might have adopted in response to the presentation of the other team.

Under no circumstances can the final resolution of the Competition Authority in question be used as an argument to defend a position. Teams are only permitted to draw on information from the relevant reports.

Other characteristics include:

1. The team representing the respondent (in cases of anti-competitive practices) or opposed to the concentration process initiates the debate. This order is maintained throughout the activity.

2. The teams can present theoretical and empirical arguments of all kinds. These should be carefully referenced and cited (preferably, supported in paper format).

3. Both the initial presentation and the summing up of arguments should be made using PowerPoint.

4. Teams seek to demonstrate that their arguments are valid or can be supported by economic theory, empirical evidence and/or the previous rulings of antitrust agencies.

On the day of the debate, each team has to submit a detailed report (8-11 pages) of its arguments, including references, industry-specific data, etc., adhering to a pre-determined format.

Each team is evaluated as follows:

a) Clarity and technical persuasiveness of argumentation [35\%].

b) Strength with which arguments are defended and rebutted. Particular importance is attached to use of technical arguments [15\%].

c) Quality of report submitted [50\%]. The evaluation takes into consideration the use made of the theoretical and empirical models presented during the lecture-based part of the course. The quality of the presentation is also a factor, albeit minor. 


\section{RESULTS}

The main aim of the debate is to ensure that students internalize the theoretical concepts presented during the course through the analysis of a real-world case study brought before the competition authorities. In addition, students are encouraged to develop their skills of presentation, their ability to defend a position by resorting to economic arguments, and their use of the tools of microeconomic analysis, statistics and even econometrics.

To determine the extent to which these objectives were being fulfilled, we conducted a survey among those students that had taken the course since its introduction (academic year 2005-2006) until the last edition (2009-10). The survey was sent out by e-mail to a total of 49 alumni. We received 27 completed questionnaires, which represents a response rate of $55 \%$, with an annual minimum of $33 \%$ (academic year 2008-09).

The survey comprised four straightforward questions which respondents were required to assess on a scale from 1 to 5 (from low to high; disagree to agree completely). To characterize the results, we included a series of personal data, and the grades obtained by each student in the debate and for the course as a whole (see Survey in Annex 1).

The students that responded to the survey had an average age of around 25 years (Table 1), 55\% of respondents were female, and $7 \%$ had been holders of Erasmus scholarship grants at the University of Las Palmas de Gran Canaria when taking the course in Industrial Economics. Of the 27 students, $48 \%$ are currently in employment (almost $20 \%$ of these work in fields related to issues of competition), while $26 \%$ are currently enrolled on, or are about to begin, a post-graduate program. As can be seen in Table 1, on average, students were awarded a better grade for Part I of the course (Government Regulation) than for Part II (Competition Policy). However, it should be noted that two different teachers were involved in the course, one of whom did not use classroom debates as a tool. Moreover, not unexpectedly, they would have had different teaching agendas.

Interestingly, the average grade awarded for Part II (Competition Policy) was 7.81, although this fell by 0.2 points when the debate was not included. The average grade awarded to students completing the debate was 8.23 . Thus, on a case-by-case basis, $75 \%$ of students were able to improve their Part II grade by participating in the debate. 


\begin{tabular}{cccccc}
\hline & Table 1: DESCRIPTIVE STATISTICS & & \\
Variable & Average & Minimum & Maximum & Deviation & Coefficient of variation \\
\hline Final grade & 8.09 & 5.43 & 9.36 & 0.94 & 0.11 \\
Part I grade: Regulation & 8.61 & 5 & 10 & 1.06 & 0.12 \\
Part II grade: Competition & 7.81 & 3.72 & 9.31 & 1.24 & 0.15 \\
Part II grade (no debate) & 7.61 & 1.60 & 9.40 & 1.60 & 0.21 \\
Debating grade & 8.23 & 5.25 & 9.75 & 3.25 & 0.15 \\
Age & 25.18 & 22 & 32 & 2.61 & 0 \\
\hline
\end{tabular}

Source: Authors' own

In part B of the questionnaire, students were asked to evaluate the course (Industrial Economics), the subject (Competition Policy) and their participation in the debate. The results are shown in Table $2^{3}$. The overall assessment of the course, subject (Part II), the debate (including improvement registered in communication skills) are positive and exceed 4 points (on a scale from 1 to 5). Thus, despite their obtaining lower grades on average in Part II (Competition Policy) of the course, the students appear to express a preference for this subject given the average rating of 4.7 points compared to 4.44 for the course as a whole.

In response to the question as to whether participating in the debate had improved their knowledge of the subject, students were again highly positive, recording an average score of 4.44. In response to the question as to whether participating in the debate had improved their communication skills, students were again largely positive (an average score of 4 ), although there was a greater dispersion in this assessment (range from 2 to 5).

\footnotetext{
3 Given the number of responses (27 from a maximum of 49 ) it is not possible to establish a causal relationship between variables, as is performed in Florido et al (2011).
} 
Table 2: ASSESSMENT OF COURSE, SUBJECT AND DEBATING TOOL

\begin{tabular}{|c|c|c|c|c|c|}
\hline Variable & Average & Minimum & Maximum & Deviation & Coefficient of variation \\
\hline Evaluation of course & 4.44 & 4 & 5 & 0.51 & 0.11 \\
\hline Evaluation of subject (Part II) & 4.74 & 4 & 5 & 0.45 & 0.09 \\
\hline Evaluation of debate & 4.44 & 3 & 5 & 0.69 & 0.16 \\
\hline Evaluation of communication skills & 4 & 2 & 5 & 0.87 & 0.22 \\
\hline
\end{tabular}

Source: Authors' own

As discussed, no econometric analysis is possible, but two correlation coefficients are, we believe, worth highlighting. The first is between the variable "evaluation of the debate" and "number of years since I attended the course". The value of 0.27 is low indicating that with increasing maturity (age and experience) students are able to view the debate (and the subject/course in general) more critically. The second is between the variable "evaluation of the debate" and the "debating grade". Were this to be close to one, it would indicate that the student responds positively simply in relation to the result obtained in the activity (recall that the survey was conducted a posteriori). However, the coefficient is 0.19 , which would tend to confirm the "sincerity" in the responses recorded in Table 2.

\section{DEBATING AND STUDENT SKILLS}

The debate, as well as improving the students' knowledge and their overall opinion of the subject, helps in a fundamental way in their acquisition of the skills that university students in the EHEA are expected to gain. The students taking this course, as part of the Economics degree, at the University of Las Palmas de Gran Canaria should acquire the following four kinds of skills:

- General skills: those acquired by all students attending university regardless of specific university or course specialization.

- Core skills: those considered specific to the University of Las Palmas de Gran Canaria, whose goal is to endow its students with a profile that reveals a true sense of their professionalism.

- Specific skills: those acquired by students graduating in Economics.

- Subject-specific skills: those acquired by successful completion of the various subjects making up the degree. 
Each of these skill areas is, we believe, specifically addressed through the implementation of the classroom debating tool. If we consider general and core skills, by debating students should learn to:

- "Communicate in an appropriate manner, being respectful of different audiences (customers, partners, developers, stakeholders, etc.), using the most appropriate forms of media and communication (in particular new information technologies and communication), so as to understand the interests, needs and concerns of individuals and organizations, while clearly expressing the meaning of the task or tasks entrusted to them and in full appreciation of how their professional knowledge can contribute to the satisfaction of those interests, needs and concerns."

- "Cooperate with other people and organizations in the efficient performance of the functions and tasks that make up their professional profile, reflecting on their own skills and professional knowledge, and demonstrating an understanding and sympathetic attitude towards the skills and knowledge of other professionals."

If we consider the specific skills, by debating students should learn to:

- "Apply professional standards to the analysis of problems and the management of technical tools."

- "Communicate fluently in their given environment and work effectively as part of a team."

- "Analyze problems critically, with precision and rigor, but without prejudice."

- "Defend a point of view, demonstrating an appreciation of the grounds on which dissenting views are based."

- "Summarize information effectively."

Thus, the introduction of classroom debating in the course of Industrial Economics, besides improving the students' knowledge of the field and their overall opinion of the course, helps them acquire a broad set of skills considered essential for students of economics. Clearly, most of the skills outlined above are unlikely to be acquired by attending conventional lectures and as such activities like debating become crucial tools in the university environment. 


\section{CONCLUSIONS}

As the literature review indicates, encouraging students to argue the knowledge they have acquired is a positive practice for the learning and assimilation of concepts (Baker et al, 2001; Lund et al, 2007). This is of particular value in the field of economics, given the ever-increasing gap between what economists study and what economists do (Colander, 2005). Thus, it is a matter of considerable urgency that we begin to develop innovative teaching techniques that facilitate learning and which, in turn, ensure that when students graduate from the economics faculties they have developed the necessary critical skills for use in the workplace and society in general.

In the present study, we have described a debating tool involving real-world cases in competition policy that has been successfully employed in an optional course, Industrial Economics II, taught to fourth-year students enrolled in the bachelor's degree in Economics at the University of Las Palmas de Gran Canaria. The tool employs all the conventional debating techniques: the defense of conflicting standpoints, turn taking, the rebuttal of the opponents arguments and the summing up of final positions.

As we discussed in our evaluation of the learning outcomes, two key objectives are met: first, key theoretical concepts are internalized; and. second, students develop skills of presenting and defending arguments in economics. Thus, students gave a more positive assessment to Part II of the course (Competition Policy), with $89 \%$ of respondents stating the debating activity helped them improve their knowledge of the subject (ratings above 4 on a scale from 1 to 5 ). At the same time, students recognized an improvement in their communication skills (with an average of 4 out of 5 on this item). Finally, the teachers involved reported that the use of the classroom debating tool had been a rewarding and motivating experience and that students had obtained higher grades thanks to their performance in the debates.

In short, the paper has shown that debating can serve as a useful classroom tool for ensuring that students acquire many of the general and specific skills that have been identified as forming part of the learning outcomes defined in the new European Higher Education Area. 


\section{References}

Arias, J.J and Walker, D.M. (2004): Additional Evidence on the Relationship between Class Size and Student Performance. The Journal of Economic Education, vol. 35, issue 4, 311-329.

Baker, M.J. (1999): Argumentation and Constructive Interaction. In G. Rijlaarsdam \& E. Espéret (Series Eds.) \& Pierre Coirier and Jerry Andriessen (Vol. Eds.) Studies in Writing: Vol. 5. Foundations of argumentative text processing, 179-202; Amsterdam: University of Amsterdam Press.

Cardell, N. S., R. Fort, W. Joerding, F. Inaba, D. Lamoreaux, R. Rosenman, E. Stromsdorfer, and R. Barlett (1996): Laboratory-based experimental and demonstration initiatives in teaching undergraduate economics. American Economic Review 86 (2): 454-59.

Carrasco, M.; Gómez, A.; Jiménez, M.; Montes, A.; Moreno, M.; Sandoval, J.C. (2006): "Metodología para el autoaprendizaje y la autoevaluación en el EEES: El debate y el examinador en el Campus Virtual - "Una experiencia interdisciplinar", Poster de las Jornadas en Redes de Investigación en Docencia Universitaria, Alicante, 5-6 Junio de 2006.

Colander, D. (2005): What Economists Teach and What Economists Do. The Journal of Economic Education, vol. 36, issue 3, 249-260.

Dickie, M. (2006): Do Classroom Experiments Increase Learning in Introductory Microeconomics? The Journal of Economic Education, vol. 37, issue 3, 267-288.

Emerson, T. L. N., and B. A. Taylor. (2004): Comparing student achievement across experimental and lecture-oriented sections of a principles of microeconomics course. Southern Economic Journal 70 (3): 672-93.

Florido, C., Jiménez, J.L. and I. Santana (2011): "Obstáculos en el camino hacia Bolonia: efectos de la implantación del EEES sobre los resultados académicos", Revista de Educación, $n^{\circ} 354$, Enero-Abril, 629-656. Ministerio de Educación, Política Social y Deporte.

Holt, C. A. (1999): Teaching Economics with Classroom Experiments. Southern Economic Journal. Vol. 65 (3), 603-10. 
Johnson, D.W., Johnson, R.T. (1992): Positive Interdependence: Key to effective cooperation. In R. Hertz-Lazarowitz and N. Miller (Eds) Interaction in cooperative groups: The theoretical anatomy of group learning (pp. 174-199). New York, Cambridge University Press.

Lund, K; Molinari, G.; Sëjouné, A.; Baker, M. (2007): How do argumentation diagrams compare when student pairs use them as a means for debate or as a tool for representing debate? International Journal of Computer-Supported Collaborative Learning, vol. 2, issues 2-3, 273-295.

Meister, J.P and Andersen, K.J (2007): A Classroom Auction with Externalities: Applied to Mergers and Acquisitions. Journal of Economic Education, vol. 38, issue 3, 297-307.

McGoldrick, K. (2008): Doing Economics: Enhancing Skills through a Process-Oriented Senior Research Course. The Journal of Economic Education, vol. 39, issue 4, 342-356.

Ruíz, M.E. (2008): El debate como instrumento de evaluación. Kikiriki. Cooperación educativa, ISSN 1133-0589, n 90, 7-8.

Slavin, R.E. (1989): Cooperative learning and achievement: Six theoretical perspectives. In C. Ames and M.L. Maehr (Eds.), Advances in motivation and achievement. Greenwich, CT: JAI Press.

Slavin, R.E. (1992): When and why does cooperative learning increase achievement? Theoretical and empirical perspectives. In R. Hertz-Lazarowitz \& N. Miller (Eds.), Interaction in cooperative groups: The theoretical anatomy of group learning 145-173. New York: Cambridge University Press.

Slavin, R.E. (1996): Research on Cooperative Learning and Achievement: What We Know, What We Need to Know. Contemporary Educational Psychology, vol. 21 (1), 43-69. 


\section{Industrial Economics II (Degree in Economics) \\ Ex-post Evaluation of the Debate}

\section{A. Personal data}

a. Age:

b. Sex:

c. Were you an Erasmus student at the ULPGC at the time of taking this course?

d. Have you completed, or are you currently enrolled on, a post-graduate program?

e. In which academic year did you study Industrial Economics II?

f. In which academic year did you finish your degree ( 0 if you have not yet graduated)?

\section{B. Questionnaire}

a. Which sector are you currently working in?

b. After graduating, have you worked in fields related to regulation of business or competition policy?

c. What rating would you give to this course in Industrial Economics? (1-Low; 5-High)

\begin{tabular}{|l|l|l|l|l|l|l|l|l|l|}
\hline 1 & & 2 & & 3 & & 4 & & 5 & \\
\hline
\end{tabular}

d. What rating would you give to the subject of Competition Policy? (1-Low; 5-High)

\begin{tabular}{|l|l|l|l|l|l|l|l|l|l|}
\hline 1 & 2 & & 3 & & 4 & & 5 & \\
\hline
\end{tabular}

e. Taking part in the Competition Policy Debate helped improve my knowledge of the subject (1-Disagree; 5-Agree Completely)

\begin{tabular}{|l|l|l|l|l|l|l|l|l|l|}
\hline 1 & & 2 & & 3 & & 4 & & 5 & \\
\hline
\end{tabular}

f. Taking part in the Debate improved my general communication skills. (1-Disagree; 5-Agree Completely)

\begin{tabular}{|l|l|l|l|l|l|l|l|l|l|}
\hline 1 & 2 & & 3 & & 4 & & 5 & \\
\hline
\end{tabular}

\section{Thank you for your participation}


WP 2011/09 "Debating as a classroom tool for adapting learning outcomes to the European higher education area" Jiménez, J.L.; Perdiguero, J. and Suárez, A.

WP 2011/08 "Influence of the claimant's behavioural features on motor compensation outcomes” Ayuso, M; Bermúdez L. and Santolino, M.

WP 2011/07 “Geography of talent and regional differences in Spain” Karahasan, B.C. and Kerimoglu E.

WP 2011/06 "How Important to a City Are Tourists and Daytrippers? The Economic Impact of Tourism on The City of Barcelona” Murillo, J; Vayá, E; Romaní, J. and Suriñach, J.

WP 2011/05 “Singling out individual inventors from patent data” Miguélez,E. and Gómez-Miguélez, I.

WP 2011/04 “La sobreeducación de los padres afecta al rendimiento académico de sus hijos?” Nieto, S; Ramos, $\mathrm{R}$.

WP 2011/03 “The Transatlantic Productivity Gap: Is R\&D the Main Culprit?” Ortega-Argilés, R.; Piva, M.; and Vivarelli, M.

WP 2011/02 “The Spatial Distribution of Human Capital: Can It Really Be Explained by Regional Differences in Market Access?" Karahasan, B.C. and López-Bazo, E

WP 2011/01 "I If you want me to stay, pay". Claeys, P and Martire, F

WP 2010/16 "Infrastructure and nation building: The regulation and financing of network transportation infrastructures in Spain (1720-2010)’Bel,G

WP 2010/15 "Fiscal policy and economic stability: does PIGS stand for Procyclicality In Government Spending?" Maravalle, A ; Claeys, P.

WP 2010/14 "Economic and social convergence in Colombia” Royuela, V; Adolfo García, G.

WP 2010/13 “Symmetric or asymmetric gasoline prices? A meta-analysis approach” Perdiguero, J.

WP 2010/12 “Ownership, Incentives and Hospitals” Fageda,X and Fiz, E.

WP 2010/11 "Prediction of the economic cost of individual long-term care in the Spanish population” Bolancé, C; Alemany, R ; and Guillén M

WP 2010/10 “On the Dynamics of Exports and FDI: The Spanish Internationalization Process” Martínez-Martín $\mathrm{J}$.

WP 2010/09 “Urban transport governance reform in Barcelona” Albalate, D ; Bel, G and Calzada, J.

WP 2010/08 “Cómo (no) adaptar una asignatura al EEES: Lecciones desde la experiencia comparada en España” Florido C. ; Jiménez JL. and Perdiguero J.

WP 2010/07 "Price rivalry in airline markets: A study of a successful strategy of a network carrier against a lowcost carrier” Fageda, X ; Jiménez J.L. ; Perdiguero , J.

WP 2010/06 "La reforma de la contratación en el mercado de trabajo: entre la flexibilidad y la seguridad" Royuela V. and Manuel Sanchis M.

WP 2010/05 "Discrete distributions when modeling the disability severity score of motor victims" Boucher, J and Santolino, M

WP 2010/04 "Does privatization spur regulation? Evidence from the regulatory reform of European airports . Bel, G. and Fageda, X."

WP 2010/03 "High-Speed Rail: Lessons for Policy Makers from Experiences Abroad”. Albalate, D ; and Bel, G."

WP 2010/02 "Speed limit laws in America: Economics, politics and geography". Albalate, D ; and Bel, G." 
WP 2010/01 "Research Networks and Inventors’ Mobility as Drivers of Innovation: Evidence from Europe” Miguélez, E. ; Moreno, R.”

WP 2009/26 "Social Preferences and Transport Policy: The case of US speed limits" Albalate, D.

WP 2009/25 "Human Capital Spillovers Productivity and Regional Convergence in Spain”, Ramos, R ; Artis, M.; Suriñach, J.

WP 2009/24 "Human Capital and Regional Wage Gaps”,López-Bazo,E. Motellón E.

WP 2009/23 “Is Private Production of Public Services Cheaper than Public Production? A meta-regression analysis of solid waste and water services” Bel, G.; Fageda, X.; Warner. M.E.

WP 2009/22 “Institutional Determinants of Military Spending” Bel, G., Elias-Moreno, F.

WP 2009/21 "Fiscal Regime Shifts in Portugal” Afonso, A., Claeys, P., Sousa, R.M.

WP 2009/20 "Health care utilization among immigrants and native-born populations in 11 European countries. Results from the Survey of Health, Ageing and Retirement in Europe” Solé-Auró, A., Guillén, M., Crimmins, E.M.

WP 2009/19 "La efectividad de las políticas activas de mercado de trabajo para luchar contra el paro. La experiencia de Cataluña” Ramos, R., Suriñach, J., Artís, M.

WP 2009/18 "Is the Wage Curve Formal or Informal? Evidence for Colombia” Ramos, R., Duque, J.C., Suriñach, J.

WP 2009/17 “General Equilibrium Long-Run Determinants for Spanish FDI: A Spatial Panel Data Approach” Martínez-Martín, J.

WP 2009/16 “Scientists on the move: tracing scientists' mobility and its spatial distribution” Miguélez, E.; Moreno, R.; Suriñach, J.

WP 2009/15 “The First Privatization Policy in a Democracy: Selling State-Owned Enterprises in 1948-1950 Puerto Rico" Bel, G.

WP 2009/14 “Appropriate IPRs, Human Capital Composition and Economic Growth” Manca, F.

WP 2009/13 “Human Capital Composition and Economic Growth at a Regional Level” Manca, F.

WP 2009/12 “Technology Catching-up and the Role of Institutions” Manca, F.

WP 2009/11 “A missing spatial link in institutional quality” Claeys, P.; Manca, F.

WP 2009/10 “Tourism and Exports as a means of Growth” Cortés-Jiménez, I.; Pulina, M.; Riera i Prunera, C.; Artís, M.

WP 2009/09 "Evidence on the role of ownership structure on firms' innovative performance” Ortega-Argilés, R.; Moreno, R.

WP 2009/08 “Por qué se privatizan servicios en los municipios (pequeños)? Evidencia empírica sobre residuos sólidos y agua" Bel, G.; Fageda, X.; Mur, M.

WP 2009/07 "Empirical analysis of solid management waste costs: Some evidence from Galicia, Spain”

Bel, G.; Fageda, X.

WP 2009/06 "Intercontinental fligths from European Airports: Towards hub concentration or not?” Bel, G.; Fageda, X.

WP 2009/05 "Factors explaining urban transport systems in large European cities: A cross-sectional approach" Albalate, D.; Bel, G. 
WP 2009/04 "Regional economic growth and human capital: the role of overeducation” Ramos, R.; Suriñach, J.; Artís, M.

WP 2009/03 "Regional heterogeneity in wage distributions. Evidence from Spain” Motellón, E.; López-Bazo, E.; El-Attar, M.

WP 2009/02 "Modelling the disability severity score in motor insurance claims: an application to the Spanish case" Santolino, M.; Boucher, J.P.

WP 2009/01 “Quality in work and aggregate productivity” Royuela, V.; Suriñach, J.

WP 2008/16 "Intermunicipal cooperation and privatization of solid waste services among small municipalities in Spain” Bel, G.; Mur, M.

WP 2008/15 "Similar problems, different solutions: Comparing refuse collection in the Netherlands and Spain" Bel, G.; Dijkgraaf, E.; Fageda, X.; Gradus, R.

WP 2008/14 "Determinants of the decision to appeal against motor bodily injury settlements awarded by Spanish trial courts" Santolino, M

WP 2008/13 "Does social capital reinforce technological inputs in the creation of knowledge? Evidence from the Spanish regions” Miguélez, E.; Moreno, R.; Artís, M.

WP 2008/12 “Testing the FTPL across government tiers” Claeys, P.; Ramos, R.; Suriñach, J.

WP 2008/11 "Internet Banking in Europe: a comparative analysis” Arnaboldi, F.; Claeys, P.

WP 2008/10 "Fiscal policy and interest rates: the role of financial and economic integration" Claeys, P.; Moreno, R.; Suriñach, J.

WP 2008/09 "Health of Immigrants in European countries” Solé-Auró, A.; M.Crimmins, E.

WP 2008/08 “The Role of Firm Size in Training Provision Decisions: evidence from Spain” Castany, L.

WP 2008/07 "Forecasting the maximum compensation offer in the automobile BI claims negotiation process" Ayuso, M.; Santolino, M.

WP 2008/06 "Prediction of individual automobile RBNS claim reserves in the context of Solvency II" Ayuso, M.; Santolino, M.

WP 2008/05 "Panel Data Stochastic Convergence Analysis of the Mexican Regions” Carrion-i-Silvestre, J.L.; German-Soto, V.

WP 2008/04 "Local privatization, intermunicipal cooperation, transaction costs and political interests: Evidence from Spain” Bel, G.; Fageda, X.

WP 2008/03 "Choosing hybrid organizations for local services delivery: An empirical analysis of partial privatization” Bel, G.; Fageda, X.

WP 2008/02 “Motorways, tolls and road safety. Evidence from European Panel Data” Albalate, D.; Bel, G.

WP 2008/01 "Shaping urban traffic patterns through congestion charging: What factors drive success or failure?" Albalate, D.; Bel, G.

WP 2007/19 "La distribución regional de la temporalidad en España. Análisis de sus determinantes” Motellón, E.

WP 2007/18 “Regional returns to physical capital: are they conditioned by educational attainment?” López-Bazo, E.; Moreno, R.

WP 2007/17 "Does human capital stimulate investment in physical capital? evidence from a cost system framework” López-Bazo, E.; Moreno, R.

WP 2007/16 "Do innovation and human capital explain the productivity gap between small and large firms?" Castany, L.; López-Bazo, E.; Moreno, R.

WP 2007/15 "Estimating the effects of fiscal policy under the budget constraint” Claeys, P. 
WP 2007/14 "Fiscal sustainability across government tiers: an assessment of soft budget constraints" Claeys, P.; Ramos, R.; Suriñach, J.

WP 2007/13 "The institutional vs. the academic definition of the quality of work life. What is the focus of the European Commission?” Royuela, V.; López-Tamayo, J.; Suriñach, J.

WP 2007/12 "Cambios en la distribución salarial en españa, 1995-2002. Efectos a través del tipo de contrato" Motellón, E.; López-Bazo, E.; El-Attar, M.

WP 2007/11 “EU-15 sovereign governments’ cost of borrowing after seven years of monetary union” GómezPuig, M..

WP 2007/10 "Another Look at the Null of Stationary Real Exchange Rates: Panel Data with Structural Breaks and Cross-section Dependence" Syed A. Basher; Carrion-i-Silvestre, J.L.

WP 2007/09 "Multicointegration, polynomial cointegration and I(2) cointegration with structural breaks. An application to the sustainability of the US external deficit” Berenguer-Rico, V.; Carrion-i-Silvestre, J.L.

WP 2007/08 "Has concentration evolved similarly in manufacturing and services? A sensitivity analysis" RuizValenzuela, J.; Moreno-Serrano, R.; Vaya-Valcarce, E.

WP 2007/07 "Defining housing market areas using commuting and migration algorithms. Catalonia (Spain) as an applied case study” Royuela, C.; Vargas, M.

WP 2007/06 "Regulating Concessions of Toll Motorways, An Empirical Study on Fixed vs. Variable Term Contracts" Albalate, D.; Bel, G.

WP 2007/05 "Decomposing differences in total factor productivity across firm size” Castany, L.; Lopez-Bazo, E.; Moreno, R.

WP 2007/04 “Privatization and Regulation of Toll Motorways in Europe” Albalate, D.; Bel, G.; Fageda, X.

WP 2007/03 "Is the influence of quality of life on urban growth non-stationary in space? A case study of Barcelona" Royuela, V.; Moreno, R.; Vayá, E.

WP 2007/02 "Sustainability of EU fiscal policies. A panel test” Claeys, P.

WP 2007/01 "Research networks and scientific production in Economics: The recent spanish experience" Duque, J.C.; Ramos, R.; Royuela, V.

WP 2006/10 “Term structure of interest rate. European financial integration” Fontanals-Albiol, H.; Ruiz-Dotras, E.; Bolancé-Losilla, C.

WP 2006/09 "Patrones de publicación internacional (ssci) de los autores afiliados a universidades españolas, en el ámbito económico-empresarial (1994-2004)" Suriñach, J.; Duque, J.C.; Royuela, V.

WP 2006/08 “Supervised regionalization methods: A survey” Duque, J.C.; Ramos, R.; Suriñach, J.

WP 2006/07 "Against the mainstream: nazi privatization in 1930s germany” Bel, G.

WP 2006/06 "Economía Urbana y Calidad de Vida. Una revisión del estado del conocimiento en España" Royuela, V.; Lambiri, D.; Biagi, B.

WP 2006/05 "Calculation of the variance in surveys of the economic climate” Alcañiz, M.; Costa, A.; Guillén, M.; Luna, C.; Rovira, C.

WP 2006/04 "Time-varying effects when analysing customer lifetime duration: application to the insurance market” Guillen, M.; Nielsen, J.P.; Scheike, T.; Perez-Marin, A.M.

WP 2006/03 "Lowering blood alcohol content levels to save lives the european experience” Albalate, D.

WP 2006/02 "An analysis of the determinants in economics and business publications by spanish universities between 1994 and 2004” Ramos, R.; Royuela, V.; Suriñach, J. 
WP 2006/01 “Job losses, outsourcing and relocation: empirical evidence using microdata” Artís, M.; Ramos, R.; Suriñach, J. 
